\title{
CMTR2 Gene
}

National Cancer Institute

\section{Source}

National Cancer Institute. CMTR2 Gene. NCI Thesaurus. Code C132034.

This gene plays a role in the methylation of the 5' mRNA cap. 